\title{
PERIOPERATIVE BLEEDING IN AN UROLOGICAL PATIENT ON ASPIRIN THERAPY
}

\author{
Natalija Vuković1, Bratislav Pejić2, Milan Lazarević ${ }^{3}$
}

\begin{abstract}
Diseases of the heart and blood vessels are the leading cause of death in Serbia, with a share of $53.7 \%$ of all causes of death. Platelets have a key role in the pathogenesis of these diseases and antiaggregation therapy is the first line of treatment. The most widely used antiaggregation drug is acetylsalicylic acid (aspirin).

The patients undergoing urological surgical treatment are mostly elderly people with cardiovascular or cerebrovascular diseases, who have aspirin included in their regular therapy. The preparation of patients for surgery and anesthesia for transurethral resection of the prostate, among other things, involves an assessment of the perioperative risk of thrombosis and bleeding.

The aim of this paper is to show the complexity of perioperative preparation of patients on aspirin for transurethral resection of the prostate in an absence of a specific guideline.

The paper illustrates a patient on aspirin, who experienced increased perioperative bleeding and postoperative complications. Increased bleeding and complications developed despite preoperative exclusion of aspirin two days before transurethral resection of the prostate.

The guidelines of the American College of Chest Physicians on perioperative management of antithrombotic therapy recommend the continuation of aspirin therapy perioperatively in patients with medium or high risk of cardiovascular events in noncardiac surgery. The guideline also emphasizes that urological procedures, including TURP, are associated with an increased risk of bleeding.

Large-scale studies are warranted in order to gain a definitive, scientifically verified view on the use of aspirin in patients undergoing transurethral resection of the prostate. Acta Medica Medianae 2017;56(4):83-89.
\end{abstract}

Key words: bleeding, aspirin, transurethral prostatectomy

\author{
${ }^{1}$ Anesthesiology and Reanimation Center, Clinical Center, Niš, \\ Serbia \\ ${ }^{2}$ Urology Clinic, Clinical Center, Niš, Serbia \\ ${ }^{3}$ Cardiovascular and Transplant Surgery Clinic, Clinical Center, \\ Niš, Serbia \\ Contact: Natalija Vuković \\ Sindjelićev trg 20/40, 18000 Niš, Serbia \\ E-mail: massha.vukovic@gmail.com
}

half-life and duration of the platelet blockade. The most commonly used drug is acetylsalicylic acid (aspirin).

Aspirin is an antiinflammatory and antiaggregation drug that irreversibly inhibits cyclooxygenase 1 (COX1) and 2 (COX2). The antiaggregation effect of aspirin is mainly achieved by inhibiting the COX1 receptor and inhibiting the synthesis of prostaglandin $\mathrm{H} 2$ ( $\mathrm{PGH} 2$ ) from arachidonic acid. Prostaglandin $\mathrm{H} 2$ is a precursor of thromboxane A2 (TXA2), responsible for platelet aggregation and vascular vasoconstriction (2). Bearing in mind that platelets have no nucleus, they cannot synthesize a new cyclooxygenase en-zyme, and the effect of aspirin lasts during the lifetime of the platelet (7-10 days). Daily synthesis of new platelets launches a gradual recovery of the overall platelet function by $10-14 \%$ per day (3). Thus, within 3-4 days in patients with normal platelet counts, about $30 \%$ of new blood platelets are synthesized, which will generally enable normal haemostasis (4).

Even very low doses of aspirin of $20-40 \mathrm{mg}$ can inhibit TxA2 in healthy volunteers (5). The increased tendency to bleed caused by aspirin is s, and each of them has its own characte tics regarding the receptor site, mode of action, 
dose-dependent, with a pronounced effect in patients who receive more than $100 \mathrm{mg}$ of aspirin per day. The antiaggregation effect of aspirin, in terms of secondary prevention of coronary and cerebrovascular diseases, is most commonly achieved with a dose of 75-100 mg per day $(6,7)$.

The patients undergoing urological surgery are mostly elderly people with a cardiovascular or cerebrovascular disease, with aspirin included in their regular therapy. Surgical interventions in the field of urology are often associated with an increased risk of thrombosis and volume of bleeding, and specific conditions for the performance of surgical haemostasis, such as the conditions in en-doscopic urology.

Endoscopic urological treatment of the majority of patients is performed in regional anesthesia, where the most serious complication is the development of spinal or epidural hematoma. The application of antithrombotic drugs, in general, is one of the main risk factors for the development of spinal and epidural hemorrhage (8). Co-administration of aspirin and low-molecular-weightheparin within the perioperative thromboprophylaxis leads to an increased rate of complications in internal medicine and in surgical patients (9). The guidelines for perioperative preparation of patients who are on aspirin therapy, and in whom regional anesthesia will be performed, are rather general, with a low level of evidence, and they are primarily based on the recommendation of experts and minor retrospective studies (10).

\section{Case Report}

Patient F. S., 73 years old, with benign prostatic hyperplasia was examined by an anesthesiologist for surgical treatment before admission to hospital. All the parameters of blood count, glicemia, urea, creatinine, electrolytes and coagulation screening were within normal ranges. Clinical examination of the heart confirmed second degree systolic murmur above the ictus without propagation. Electrocardiography (ECG) showed sinus tachycardia, heart rate $100 / \mathrm{min}$, transient zone in V4 and horizontal ST depression of V4-V6 segments from $1-2 \mathrm{~mm}$. Ultrasound examination of the heart indicated, among other normal findings, concentric hypertrophy of the left ventricle, mitral and aortic regurgitation $1+$. Based on the report of the prehospital internist, it was concluded that the patient had been treated with the diagnosis of chronic ischemic cardiomyopathy, and the therapy included a $\beta$-blocker, an angiotensine-converting enzyme inhibitor, molsidomine, and $100 \mathrm{mg}$ of aspirin. The patient denied chest pain and dyspnea in the last 6 months, as well as previous hospitalizations for these. The available documentation did not contain any stress testing. The patient had normal auscultatory findings of the lungs and he denied other important diseases, bleeding tendency, and previous surgery.

After the examination by an anesthesiologist, the physical status of the patient was esti- mated as ASA 2, according to the American Society of Anesthesiologists (11). The patient was instructed to discontinue aspirin for 3 days before elective surgical intervention under the Local Protocol of the Anesthesiology Department.

The day before the planned surgery of transurethral resection of the prostate, the patient $F$. S. was admitted to the Urology Clinic Niš. On the pre-anesthetic visit, it was found that the patient had not been taking aspirin for 2 days and that the day of the surgery would be the third day of aspirin discontinuation. The night before the intervention, the patient received a single dose of low molecular weight heparin within the protocol of preoperative thromboprophylaxis of patients in the Urology Clinic in Niš.

The following day, after premedication, the planned surgery began. It was conducted under total intravenous anesthesia with propofol, fentanyl and rocuronium, with continuous monitoring of vital parameters, microstream-enabled capnography, ECG and bispectral index monitoring. As early as 20 minutes after the surgery started, the presence of extensive bleeding was indicated on the basis of intensity of staining of the fluids for bladder irrigation in the aspirator. The urologist drew attention to the fact the patient bled more intensely than usual despite attempted chemostasis at each contact with a resectoscope. The next step was the opening of a new venous access, blood sampling for determining emergency blood count, blood and platelet acquisition, analysis of rotational thromboelastometry and analysis of platelet function. The patient was compensated for the estimated loss of intravascular volume, stress ulcer was prevented by including proton pump inhibitors, and antibiotics were included at the beginning of the intervention according to the urine culture. As part of the treatment of the resultant bleeding, tranexamic acid was introduced at a dose of $10 \mathrm{mg} / \mathrm{kg}$ in slow bolus followed by another $5 \mathrm{mg} / \mathrm{kg}$ in continuous infusion, continued in the intensive care unit. After 90 minutes of surgical treatment and primary hemorrhage stabilization, the patient was, after awakening, transferred into the intensive care, which was followed by an intensive lavage and irrigation of the bladder. In a short time, based on the results of platelet function, where a moderate antiplatelet effect of aspirin on COX1 receptor blockade was determined (Figure 1), desmopressin at a dose of $20 \mu \mathrm{g} / 20 \mathrm{ml}$ $(0.3-0.4 \mu \mathrm{g} / \mathrm{kg})$ was introduced for $20 \mathrm{~min}$ in parallel with the use of tranexamic acid. Thromboelastometry findings indicated physiological parameter values (Figure 2). Shortly after the administration of desmopressin, bladder irrigation became less hematuric, remaining the same until evening, when it deteriorated to a lesser degree again. On that occasion, hematuria was solved by intense bladder lavage and irrigation. On the day of the surgery the patient received one unit of blood and during the next day one more. After receiving the analyses results, and after establishing a suspicion that the patient was at risk of tran- 


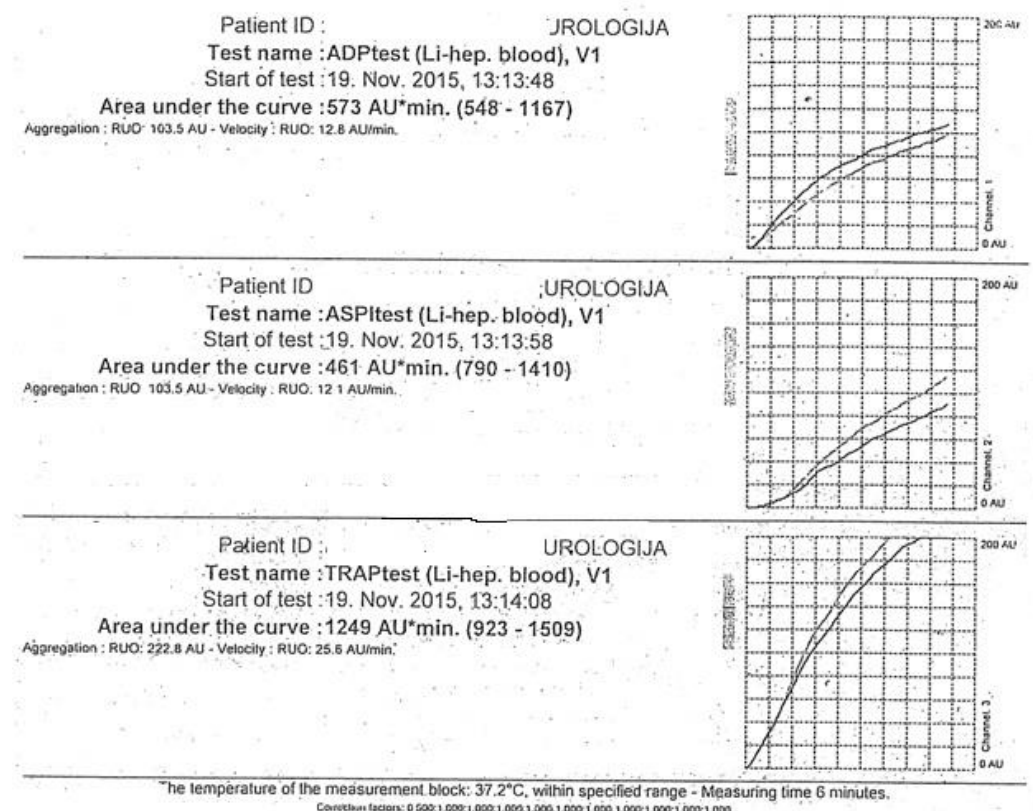

Figure 1. Platelet aggregation test performed immediately after the patient admission to the ICU

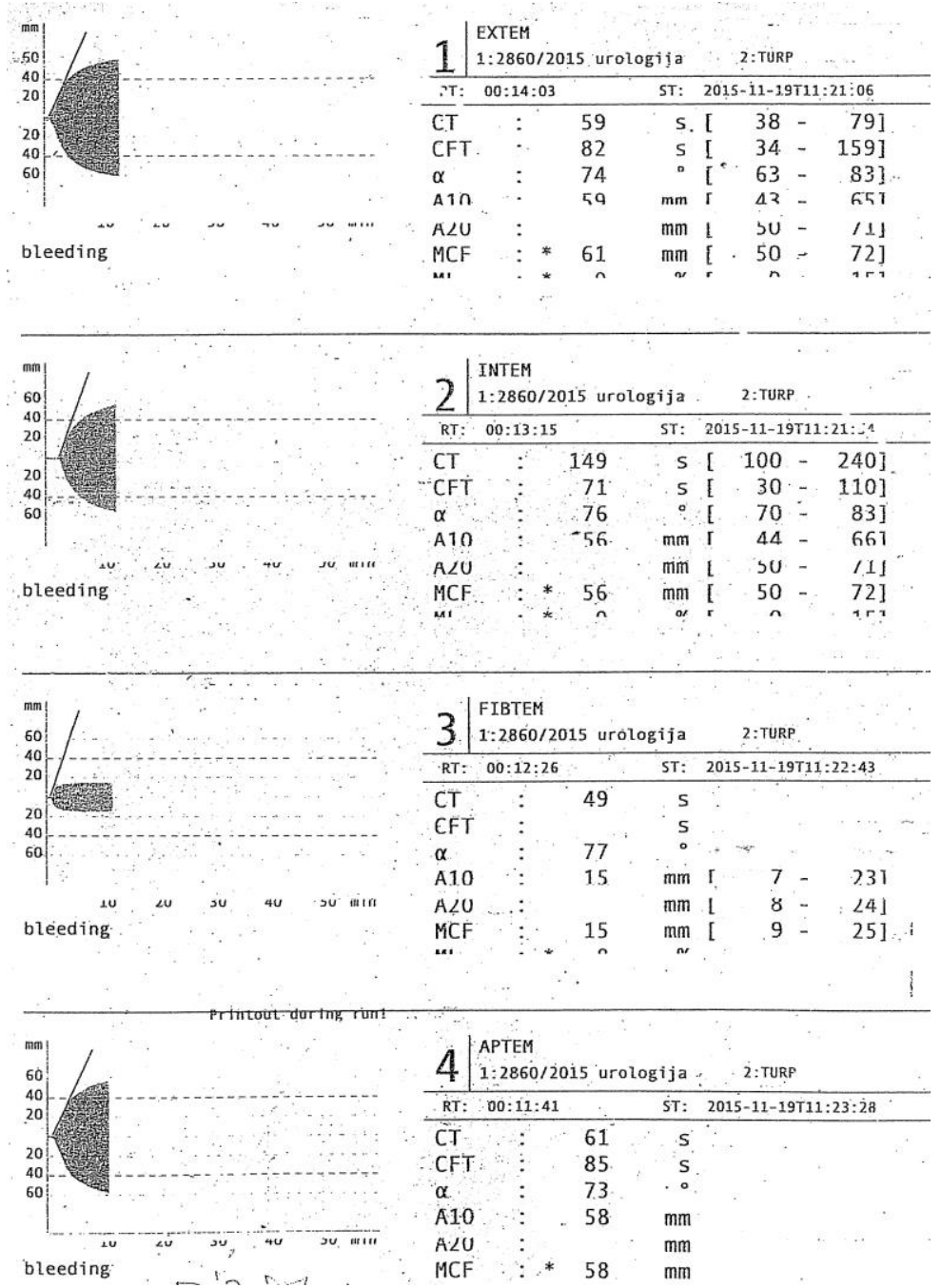

Figure 2. Rotational thromboelastometry graphic tracings 
surethral resection of prostate (TURP) syndrome, he was administered diuretic treatment and fluid resuscitation solutions were replaced by $0.9 \%$ $\mathrm{NaCl}$ solution.

In the period to follow, the patient had no more episodes of bleeding. Postoperatively, the patient was treated for the TURP syndrome, acute infection, and post-operative acute kidney injury (12), due to a double postoperative creatinine elevation. On the third postoperative day, the patient returned to aspirin therapy. Eight days after the surgery, the patient was discharged home in good general condition and with normal values of urea, creatinine and electrolytes.

\section{Discussion}

Aspirin inhibits platelet aggregation, prevents thrombosis, and plays an important role in primary prevention (prevention of the first occurrence) and secondary prevention (prevention of recurrence) of acute heart attack and stroke. In this case report, aspirin therapy was administered as part of the secondary prophylaxis of cardiocerebral events. Any discontinuation of aspirin in patients on secondary prophylaxis is associated with a significant increase in the risk of recurrent ischemic events (13). The period from the discontinuation of aspirin to the occurrence of acute cardiovascular events was $8.5 \pm 3.6$ for acute coronary syndrome and $14.3 \pm 11.3$ days for acute cerebral events (14). The discontinuation of aspirin resulted in the rebound phenomenon characterized by an increased synthesis of thromboxane, intense thrombus stability and reduced fibrinolysis $(15,16)$. It is known that the perioperative period itself represents a risk for thrombosis. Sympathetic hyperreactivity in the course of a surgical intervention leads to hypercoagulability and reduction of fibrinolysis. Perioperatively, platelet activation occurs and is caused by a decrease in blood flow, release of platelet-activating factor of the tissue, hypothermia, sepsis (17). In the light of the above, it should be noted that the most common perioperative complication in coronary patients in a non-cardiac surgery is myocardial infarction, with a mortality rate of $15-25 \%$ (18).

The studies dealing with the increased risk of perioperative bleeding in patients on aspirin treated with TURP are conflicting. Aspirin can cause increased perioperative bleeding during a TURP procedure, partly due to the presence of endogenous urokinase and blood hemodilution caused by the irrigation fluid at the site of resection of the prostate and vascular bed exposure. Two studies in the 1990s $(19,20)$ showed increased postoperative bleeding and the need for significantly more blood transfusions in patients with TURP performed with perioperative continuation of aspirin. Nielsen and associates (21) recommended a discontinuation of aspirin for 10 days, after establishing a significant increase in postoperative bleeding in patients on aspirin compared to subjects on placebo. A meta-analysis by Burger et al. (14) investigated and compared the risk of thrombosis in perioperative discontinuation of aspirin versus the risk of bleeding in patients who continued using aspirin perioperatively. According to this study, preoperative aspirin discontinuation preceded $10 \%$ of cardiovascular and cerebrovascular complications (myocardial infarction, stroke, peripheral arterial occlusion, sudden cardiac death). Taking aspirin in the immediate perioperative period caused an increase in the incidence of bleeding by $50 \%$, but without any additional adverse effects on morbidity and mortality, except in the case of intracranial surgery and transurethral prostatectomy. The authors recommended the suspension of aspirin only if the risk of bleeding exceeds the cardiovascular risks. The latest guidelines of the American College of Chest Physicians on perioperative management of antiplatelet therapy (2) recommend the continuation of aspirin perioperatively in patients with medium or high risk of cardiovascular events in non-cardiac surgery. The guidelines also emphasize that urological procedures, including TURP interventions, are associated with an increased risk of bleeding.

Practical testing of these guidelines gives variable results. The study conducted in the UK (22) found that $45 \%$ of urologists did not discontinue aspirin perioperatively in patients for TURP. According to the results of this study, aspirin was discontinued on the average 7-9 days before the surgery, and in some institutions, up to 15 days. In our case, the patient was operated two days after the discontinuation of aspirin from regular therapy. Various studies of healthy volunteers (23) and cardiac patients (24) identified the return of normal platelet function in $80 \%$ of patients within $96 \mathrm{~h}$ or $72 \mathrm{~h}$ after aspirin discontinuation. The Local Protocol in the Urology Clinic in Niš is based on the fact that the daily synthesis of new platelets leads to a gradual recovery of the total platelet function within 3 to 4 days in patients with physiological platelet counts $(3,4)$.

The patient presented in this paper had severe perioperative bleeding. A difficult chemostasis from all areas of the resection tissue was detected intraoperatively, and blood was sampled for thromboelastography and platelet aggregation testing. The platelet aggregation test showed the presence of a partial blockage of aspirin receptor on platelets, or a moderate disorder of platelet aggregation caused by aspirin (Figure 1). Rotational thromboelastometry removed the doubt about the existence of other disorders of coagulation and fibrinolysis in the patient (Figure 2). The therapy with desmopressin and tranexamic acid began intra-operatively and was continued immediately post-operatively, which quickly reduced bleeding. It was interesting that bleeding intensified again after the half-life of desmopressin, however, with a lower intensity than in the first wave.

The anesthesiology aspect of a TURP procedure, in addition to the above considerations, refers also to the consideration of risk of spinal or epidural hematomas while performing regional anesthesia, as well as the issue of perioperative thromboprophylaxis. According to the latest guidelines of the European Society of Anesthesiologists 
on the issue of regional anesthesia and application of antithrombotic drugs (11), the use of aspirin and non-steroidal anti-inflammatory drugs in general in isolation, does not increase the risk of spinal epidural hematoma, and these drugs are not contraindicated in neuraxial anesthesia (class IIb, level C).

Regarding the issue of perioperative thromboprophylaxis, according to the Stafford-Smith study (9), although the use of aspirin in isolation does not increase the risk of hematoma formation, there is a higher rate of complications in both surgical and internal medicine patients when heparins are used simultaneously. The European guidelines in anesthesiology (11) conclude that, since preoperative versus postoperative thromboprophylaxis is not proven useful, the recommended cautious approach in patients on aspirin represents a postoperative initiation of thromboprophylaxis (Class I, Level B). Given that the patient we presented received a prophylactic dose of low molecular weight heparin in the evening before intervention, and thereby had a residual aspirin effect, the decision to perform general endotracheal anesthesia seems to be justified.
Bearing in mind the patient presented here, as well as the absence of guidelines in urological surgery on the application and/or discontinuation of aspirin perioperatively, the question remains regarding the best course of action to be taken in the preparation of cardiac patients for a TURP surgery.

\section{Conclusion}

Transurethral resection of the prostate stands out as one of the surgical procedures with evidenced increases in morbidity and mortality from bleeding caused by perioperative continuation of aspirin therapy. In this paper, we presented a patient in whom aspirin therapy was suspended two days before a TURP surgery, which led to increased perioperative bleeding and the occurrence of postoperative complications.

Large-scale studies should be undertaken to determine definitive, scientifically proven guidelines concerning the application of aspirin in patients undergoing transurethral resection of the prostate.

\section{References}

1. Institut za javno zdravlje Srbije ,,dr Milan Jovanović Batut". Nezarazni poremećaji zdravlja. U Zdrvstveno-statistički godišnjak Republike Srbije 2013. Beograd: Elit medica; 2014.

2. Douketis JD, Spyropoulos AC, Spencer MD, Mayr M, Jaffer AK, Eckman $\mathrm{MH}$, et al. Perioperative Management of antithrombotic therapy. Chest 2012; 141 (2 Suppl): 326-50. [CrossRef] [PubMed]

3. Oprea A.D, Popescu W.M. Perioperative management of antiplatelet therapy. $\mathrm{Br} \mathrm{J}$ Anaesth 2013; 11 (S1): i3-i17. [CrossRef] [PubMed]

4. Gibbs NM, Weightman WM, Tackray NM, Michalopoulos N, Weidmann C.The effects of recent aspirin ingestion on platelet function in cardiac surgical patients. ] Cardiothorac Vasc Anesth 2001; 15: 55-59. [CrossRef] [PubMed]

5. Patrignani $P$, Filabozzi $P$, Patrono $C$. Selective cumulative inhibition of platelet thromboxane production by low-dose aspirin in healthy subjects. J Clin Invest 1982; 69: 1366-72. [CrossRef] [PubMed]

6. Lewis HD, Davis JW, Archibald DG, Steinke WE, Smitherman TC, Dohert JE et al. Protective effects of aspirin against acute myocardial infarction and death in men with unstable angina. Results of a Veterans Administration Cooperative Study. N Engl J Med 1983; 309: 396-403. [CrossRef] [PubMed]

7. Antithrombotic Trialists' Collaboration. Collaborative meta-analysis of randomised trials of antiplatelet therapy for prevention of death, myocardial infarction, and stroke in high risk patients. $\mathrm{Br}$ Med J 2002; 324: 71-86. [CrossRef] [PubMed]

8. Moen V, Dahlgren N, Irestedt L. Severe neurological complications after central neuraxial blockades in Sweden 1990-1999. Anesthesiology 2004; 101: 950-959. [CrossRef] [PubMed]

9. Stafford-Smith M. Impaired haemostasis and regional anaesthesia. Can J Anaesth 1996; 43: R129-R141. [CrossRef] [PubMed]

10. Gogarten W, Vandermeulen E, Van Aken H,Kozek S, Llau JV, Samama CM. Regional anaesthesia and antithrombotic agents: recommendations of the European Society of Anaesthesiology. Eur J Anaesthesiol 2010; 27(12): 999-1015. [CrossRef] [PubMed]

11. ASA physical status classification system- American society of anesthesiologists (last approved by the ASA House of Delegates 2014 October $15^{\text {th }}$ ) Available from: URL:http://www.asahq.org/ / media/sites/asahq/files/public/resources/standardsguidelines/asa-physical-status-classificationsystem.pdf

12. Bellomo R, Ronco C, Kellum AJ, Mehta RL, Palevsky $P$ and the ADQI workgroup. Acute renal failuredefinition, outcome measures, animal models, fluid therapy and information technology needs:the Second International Consensus Conference of the acute dialysis quality initiative (ADQJ) group. Critical Care 2004; 8: R204-R12. [CrossRef] [PubMed] 
13. Oscarsson A, Gupta A, Fredericson M, Jarhult J, Nystrom M, Pettersson $E$ et al. To continue or discontinue aspirin in the perioperative period: a randomized, controlled clinical trial. $\mathrm{Br}$ J Anaesthesia. 2010; 104: 305-12. [CrossRef] [PubMed]

14. Burger W, Chemnitius JM, Kneissl GD, Rucker G. Low dose aspirin for secondary cardiovascular prevention- cardiovascular after its perioperative withdrawal versus bleeding risks with its continuation-review and meta-analysis. J Inter Med 2005; 257: 399-414. [CrossRef] [PubMed]

15. Beving $\mathrm{H}$, Zhao $\mathrm{C}$, Albage A, Ivert $\mathrm{T}$. Abnormally high platelet activity after discontinuation of acetylsalicylic acid treatment. Blood Coagul Fibrinolysis 1996; 7: 80-4. [CrossRef] [PubMed]

16. Gerstein NS, Schulman PM, Gerstein WH, Petersen $T R$, Tawii I. Should more patients continue aspirin therapy perioperatively?: clinical impact of aspirin withdrawal syndrome. Ann Surg 2012; 255: 81119. [CrossRef] [PubMed]

17. Devereaux PJ, Goldman L, Cook DJ, Gilbert K, Leslie K, Guyatt GH. Perioperative cardiac events in patients undergoing noncardiac surgery: a review of the magnitude of the problem, the pathophysiology of the events and methods to estimate and communicate risk. CMAJ 2005; 173: 627-634. [CrossRef] [PubMed]

18. Peter $\mathrm{K}$, Myles PS. Perioperative antiplatelet therapy: a knife-edged choice between thrombosis and bleeding still based on consensus rather than evidence. Thromb Haemost 2011; 105: 1-2. [CrossRef] [PubMed]

19. Wierod FS, Frandsen NJ, Jacobsen JD, Hartviqsen $A$, Olsen PR. Risk of hemorrhage from transurethral prostatectomy in acetylsalicylic acid and NSAIDtreated patients. Scand J Urol Nephrol 1998; 32: 120-2. [CrossRef] [PubMed]

20. Thurston AV, Briant SL. Aspirin and postprostatectomy haemorrhage. $\mathrm{Br}$ J Urol 1993; 71: 574-6. [CrossRef] [PubMed]

21. Nielsen JD, Holm-Nielsen A, Jespersen J, Vinther CC, Settqast IW, Gram J. The effect of low-dose acetylsalycilic acid on bleeding after transurethral prostatectomy-a prospective, randomized, doubleblind, placebo-controlled study. Scand J Urol Nephrol 1996; 30: 203-6. [PubMed]

22. Davis NF, McGuire BB, Flood HD. Perioperative management of antithrombotic agents in urological surgery. Br J Urol 2011; 4: 187-96. [CrossRef]

23. Jimenez $A H$, Stubbs $M E$, Tofler $G H$, Winther $K$, Williams GH, Muller JE. Rapidity and duration of platelet suppression by enteric-coated aspirin in healthy young men. Am J Cardiol 1992; 69: 25862. [CrossRef] [PubMed]

24. Furukawa $\mathrm{K}$, Ohteki H. Changes in platelet aggregation after suspension of aspirin therapy. J Thorac Cardiovasc Surg 2004; 127: 1814-5. [CrossRef] [PubMed] 


\title{
PERIOPERATIVNO KRVARENJE KOD UROLOŠKOG BOLESNIKA NA TERAPIJI ASPIRINOM
}

\author{
Natalija Vuković ${ }^{\text {, Bratislav Pejić }}$, Milan Lazarević ${ }^{3}$
}

\author{
${ }^{1}$ Centar za anesteziologiju i reanimaciju, Klinički centar, Niš, Srbija \\ ${ }^{2}$ Klinika za urologiju, Klinički centar, Niš, Srbija \\ ${ }^{3}$ Klinika za kardiovaskularnu hirurgiju sa transplantacijom, Klinički centar, Niš, Srbija \\ Kontakt: Natalija Vuković \\ Sindjelićev trg 20/40 \\ 18000 Niš, Srbija \\ E-mail: massha.vukovic@gmail.com
}

Bolesti srca i krvnih sudova vodeći su uzrok umiranja u Srbiji, sa učešćem od $53,7 \%$ kod svih uzroka smrti. Ključnu ulogu u patogenezi ovih bolesti imaju trombociti, pri čemu antiagregaciona terapija predstavlja prvu liniju lečenja. Najčešće primenjivani antiagregacioni lek je acetilsalicilna kiselina (aspirin).

Bolesnici koji se podvrgavaju urološkom hirurškom lečenju najčešće su starije osobe sa kardiovaskularnom ili cerebrovaskularnom bolešću, kojima je u redovnu terapiju uključen aspirin. Priprema za operaciju i anesteziju bolesnika transuretralne resekcije prostate, pored ostalog, podrazumeva procenu perioperativnog rizika i od tromboze i od krvarenja.

Cilj ovog rada bio je prikaz kompleksnosti perioperativne pripreme bolesnika na aspirinu za operaciju transuretralne resekcije prostate u odsustvu jedinstvenih vodiča.

$\mathrm{U}$ radu je prikazan bolesnik na aspirinu kod koga je došlo do povećanog perioperativnog krvarenja i postoperativnih komplikacija. Do razvoja povećanog krvarenja i komplikacija došlo je i pored preoperativnog isključenja aspirina dva dana uoči transuretralne resekcije prostate.

Vodiči Američkog udruženja grudnih lekara o perioperativnoj primeni antitrombotske terapije preporučuju nastavak primene aspirina perioperativno kod bolesnika sa srednjim ili visokim rizikom od nastanka kardiovaskularnih događaja u nekardiološkoj hirurgiji. U vodičima se naglašava da urološke procedure, među kojima i TURP, predstavljaju intervencije sa povećanim rizikom od krvarenja.

Postoji neophodnost sprovođenja velikih studija radi utvrđivanja definitivnog naučno dokazanog stava o primeni aspirina kod bolesnika za operaciju transuretralne resekcije prostate.

Acta Medica Medianae 2017;56(4):83-89.

Ključne reči: krvarenje, aspirin, transuretralna prostatektomija 